\title{
Notes
}

On Forster see above, p. 43. The incident described took place in about $1870-2$.

1 Frederick Lehmann (1826-91), with his wife Nina long a friend of Browning in London.

2 Ernest L. Benzon (1819-73), industrialist, Frederick Lehmann's business partner. Browning stayed at his Perthshire estate in the summer of 1871 while writing Prince Hohenstiel-Schwangau.

3 Landseer (1802-73), painter best known for his studies of animals.

\section{Browning's Conversation in 1872: port, a pun and financial matters}

\section{Cornelia Crosse}

In 1872 I had the pleasure of meeting Mr Browning again ... $\mathrm{Mr}$ Browning was very intimate at the house where we were dining, and I noticed that one of the servants placed a decanter of port wine near him, offering him no other during dinner. On [my] expressing my surprise at his drinking port, having been so long in Italy, he replied 'It is because I have been so long in Italy that I am tired of their sour wines.' In the course of conversation I mentioned that an accident had happened to our gas meter, and that when I left my house the place was in darkness. 'I should not be surprised if the same thing occurred to me,' said Mr Browning, 'for my critics tell me there is something very wrong with my metre.' The reviews of 'The Ring and the Book' were then appearing.

In conversation he was a many-sided man. I have heard him talk on financial matters as Solomon might have spoken had he been a member of the Stock Exchange. Mr Browning's enthusiasm for Italy did not prevent a feeling of soreness at their taxing his interest coupons.

[Mrs Andrew Crosse], 'The Brownings', Littell's Living Age, 192, 19 March 1892, pp. 726-7

\section{Notes}

Cornelia Crosse was the second wife of the 'electro-chemical philosopher' (DNB) Andrew Crosse (1784-1855). 